\author{
Matgorzata Milczarek, Mirosław P Czarkowski, Matgorzata Sadkowska-Todys
}

\title{
SALMONELLOSIS IN POLAND IN 2015 AND 2016*
}

\author{
SALMONELOZY W POLSCE W 2015 I 2016 ROKU*
}

National Institute of Public Health - National Institute of Hygiene in Warsaw,

Department of Epidemiology of Infectious Diseases and Surveillance

Narodowy Instytut Zdrowia Publicznego - Państwowy Zakład Higieny w Warszawie,

Zakład Epidemiologii Chorób Zakaźnych i Nadzoru

\begin{abstract}
THE AIM. The aim of the study is to assess the epidemiological situation of salmonellosis in 2015-2016 in Poland, compared to the previous years.

MATERIAL AND METHODS. The assessment of the epidemiological situation was performed on the basis of data from bulletins "Infectious diseases and poisonings in Poland", information from the laboratories of Sanitaryepidemiological Stations and data from epidemiological investigations of outbreaks which were provided by Sanitary-epidemiological Stations through the Register of Epidemic Outbreaks (ROE) to the Department of Epidemiology of Infectious Diseases and Surveillance as well as data from the Department of Demographic Studies of the Central Statistical Office. Cases were classified according to the implemented case definitions.

RESULTS. In 2015, a total of 8650 cases salmonellosis were reported. Among them 8418 were cases of intestinal salmonellosis and 232 of extraintestinal one. Total incidence was 22.5/100 000. $8235(95,2 \%)$ cases met the criteria for confirmed case and 415 cases were classified as probable. In comparison to 2014, the percentage of hospitalized persons increased slightly and remained at a high level of $71.8 \%$. The increase of salmonellosis cases, as in previous years, occurred in the summer months. In 2015 he highest incidence was recorded in the Małopolskie and Mazowieckie voivodeships, and the lowest in the Lubuskie. Children 0-4 were most often affected, especially at the age of 2 and 3 years old.

Number of reported foodborne outbreaks caused by Salmonella was 190. Among them 154 were caused by Salmonella Enteritidis. This serotype, as in previous years was the most frequently isolated. Out of the 433571 tested people who were working with food, $0.2 \%$ were infected with Salmonella.

In 2016, the total number of reported cases of salmonellosis was 10,027 cases, which was close to $16 \%$ increase in cases compared to the previous year and over 19\% increase compared to 2014 . There were registered 9,701 cases of intestinal and 326 extraintestinal infections. 9,713 cases were classified as confirmed, accounting for $96.9 \%$ of all and 314 cases were classified as probable ones. The percentage of hospitalizations in 2016 remained at a similar level as in previous years (71.1\%). The peak of incidence as in the previous year was in July. The highest numbers of cases were recorded in the Małopolskie and Mazowieckie voivodeships, which accounted for $23 \%$ of all reported cases. As in previous years, most often affected were children at the age $0-4$. In 2016 number of reported outbreaks of foodborne infections caused by Salmonella sp. was 240 . In $85 \%$ of them $S$. Enteritidis serotype was isolated, which as in previous years was the serotype most frequently isolated in outbreaks and sporadic diseases. Among 443419 people working with food who were tested for Salmonella $0,2 \%$ were positive, as in the previous year.

CONCLUSIONS. The increase in the incidence of salmonellosis in 2015-2016 in Poland may be related to the outbreak detected in 2016, covering more than a dozen EU countries, associated with eggs originating in Poland. Observed in the last several years high percentage of hospitalizations due to salmonellosis is a consequence of rare laboratory testing for salmonellosis by GPs of patients with gastroenteritis. It also results in the low sensitivity of salmonella surveillance in Poland.
\end{abstract}

Key words: salmonellosis, intestinal salmonellosis, extraintestinal salmonellosis, epidemiology, Poland, 2015, 2016

\footnotetext{
*Article was written under the task No.7/EM.1/2018/ Praca została wykonana w ramach zadania nr 7/EM.1/2018

(C) National Institute of Public Health - National Institute of Hygiene / Narodowy Instytut Zdrowia Publicznego - Państwowy Zakład Higieny
} 


\section{STRESZCZENIE}

CEL. Celem pracy jest ocena sytuacji epidemiologicznej salmonelozy w latach 2015-2016 w Polsce, w porównaniu do lat poprzednich.

MATERIAL I METODY. Ocena sytuacji epidemiologicznej została przeprowadzona na podstawie danych z biuletynów „Choroby zakaźne i zatrucia w Polsce”, informacji z laboratoriów stacji sanitarno-epidemiologicznych i z danych z dochodzeń epidemiologicznych w ogniskach przekazanych przez stacje sanitarno-epidemiologiczne poprzez system Rejstr Ognisk Epidemicznych (ROE) do Zakładu Epidemiologii Chorób Zakaźnych i Nadzoru oraz danych pochodzących z Departamentu Badań Demograficznych Głównego Urzędu Statystycznego. Zachorowania kwalifikowano na podstawie obowiązujących definicji przypadku.

WYNIKI. W 2015 r. w Polsce zgłoszono łącznie 8650 przypadków zachorowań o etiologii salmonelozowej, 8418 to przypadki salmonelozy jelitowej, 232 pozajelitowej. Zapadalność ogółem wyniosła 22,5 na 100000 ludności. Zarejestrowano 8235 przypadków potwierdzonych, co stanowiło 95,2\% wszystkich zachorowań oraz 415 przypadków prawdopodobnych. W porównaniu do 2014 r. odsetek osób hospitalizowanych nieznacznie wzrósł i dalej utrzymywał się na wysokim poziomie $71,8 \%$. Wzrost zachorowań na salmonelozy odzwierzęce, podobnie jak w latach poprzednich, przypadł na miesiące letnie. Najwięcej zachorowań w 2015 r. odnotowano w województwie małopolskim i mazowieckim, najmniej w województwie lubuskim. Najczęściej chorowały dzieci w przedziale wiekowym 0-4, głównie dzieci w wieku od 1 do 2 r.ż. Zgłoszono 190 ognisk zatruć pokarmowych wywołanych pałeczkami Salmonella, w tym 154, których czynnikiem etiologicznym były pałeczki Salmonella Enteritidis. Ten typ serologiczny podobnie jak w latach ubiegłych był najczęściej izolowanym serotypem. Wśród przebadanych 433571 osób pracujących z żywnością, u $0.2 \%$ z nich wyizolowano pałeczki Salmonella.

W 2016 r. liczba zachorowań na salmonelozy wyniosła łącznie 10027 przypadków, co oznacza prawie 16\% wzrost zachorowań w porównaniu do roku poprzedniego oraz ponad 19\% wzrost w porównaniu do roku 2014. Zarejestrowano 9701 przypadków samonelozy jelitowej i 326 pozajelitowej. Zaklasyfikowano 9713 przypadków jako potwierdzone, co stanowi 96,9\% wszystkich przypadków salmoneloz oraz 314 przypadków jako prawdopodobne. Odsetek hospitalizacji w $2016 \mathrm{r}$. utrzymał się na podobnym poziomie jak w latach poprzednich i wniósł $71,1 \%$. Szczyt zachorowań, tak samo jak rok wcześniej, miał miejsce w lipcu. Najwięcej przypadków odnotowano w województwie małopolskim i mazowieckim, zachorowania te stanowią 23\% wszystkich zarejestrowanych salmoneloz. Podobnie jak w latach ubiegłych najczęściej chorowały dzieci w wieku od 0 do 4 lat. Zgłoszono 240 ognisk zatruć pokarmowych spowodowanych pałeczkami Salmonella, w $85 \%$ z nich wyizolowano serotyp Enteritidis, który tak samo jak w latach wcześniejszych był głównym serotypem izolowanym w ogniskach oraz zachorowaniach sporadycznych. Odsetek osób pracujących z żywnością, mających dodatni wynik badania w kierunku pałeczek Salmonella wyniósł tak jak rok wcześniej 0,2\% (z 443419 przebadanych osób).

WNIOSKI. Wzrost liczby zachorowań na salmonelozy w latach 2015-2016 jest prawdopodobnie w dużej części wynikiem wykrytego w 2016 r. ogniska obejmującego kilkanaście krajów UE, mającego powiązanie z jajami pochodzącymi z Polski.

W dalszym ciągu obserwowany jest wysoki odsetek osób hospitalizowanych z powodu salmonelozy - jest to konsekwencją zlecania przez lekarzy pierwszego kontaktu zbyt małej liczby badań laboratoryjnych u chorych z nieżytem żołądkowo-jelitowym, co skutkuje również niedorejestrowaniem przypadków salmonelozy w Polsce.

Słowa kluczowe: salmonelozy, salmonelozy jelitowe, salmonelozy pozajelitowe, epidemiologia, Polska, 2015, 2016

\section{INTRODUCTION}

In the European Union Salmonella sp. is the second, just behind Campylobacter, most frequent cause of human gastroenteritis. In 2015, a total of 94,625 human salmonellosis cases were recorded in the 28 EU countries, and the incidence was 21.2/100,000 (1). Poland accounted for $9.14 \%$ of these cases. In 2016, in EU 95,430 cases of salmonellosis were reported, of which $10.6 \%$ occurred in Poland (2). Within two years (2015-2016), in the European Union, Salmonella was the cause of 254 deaths.

\section{WSTĘP}

$\mathrm{Na}$ drugim miejscu, zaraz po bakteriach z rodzaju Campylobacter, pałeczki Salmonella są najczęściej występującym w Unii Europejskiej czynnikiem etiologicznym powodującym zachorowania, którym towarzyszy nieżyt żołądkowo jelitowy. W 2015 r. w 28 krajach UE zarejestrowano łącznie 94625 przypadków salmoneloz u ludzi, a zapadalność wyniosła 21,2 na 100 tys. ludności (1). Przypadki z Polski stanowią 9,14\% tych zachorowań. W 2016 r. w krajach UE zachorowało łącznie 94530 osób, z czego 10,6\% przy- 
Both intestinal and extraintestinal salmonellosis is in Poland subject of obligatory reporting. The purpose of this study is the assessment of the epidemiological situation of salmonellosis in Poland in 2015-2016 in comparison to the previous years.

\section{MATERIAL AND METHODS}

The epidemiological situation of salmonellosis in Poland in 2015 and 2016 has been analyzed on the basis of data included in the relevant annual bulletins "Infectious diseases and poisoning in Poland" (NIZPPZH, GIS, Warsaw), information from the laboratories of Sanitary-epidemiological Stations and data from epidemiological investigations of outbreaks which were provided by Sanitary-epidemiological Stations through the Register of Epidemic Outbreaks (ROE) to the Department of Epidemiology of Infectious Diseases and Surveillance as well as data from the Department of Demographic Studies of the Central Statistical Office.

Enteric salmonellosis is classified based on a case definition that was adopted by the European Commission by decision of 28 April 2008, amending decision number 2002/253 / EC. In 2009 it was introduced to routine surveillance in Poland

\section{RESULTS}

In Poland, in 2015, the number of reported cases of salmonellosis was 8,650 , including 8818 intestinal salmonellosis and 232 cases of extraintestinal salmonellosis (3) (tab. I). In comparison to 2014, it was an increase of 221 cases. The incidence was $22,5 / 100,000$, which in comparison to the previous year was an increase of $0.7 / 100,000$.

In 2016, the incidence of salmonellosis in relation to the previous year increased by $16 \%$, there were a total of 10,027 cases, which included 9,701 cases of intestinal salmonellosis and 326 cases of extraintestinal salmonellosis. In comparison to 2014, the total number of cases of salmonellosis increased by over $19 \%$ (4).

In 2015, salmonellosis were the direct cause of 5 deaths, while in 2016 of 8 deaths. In comparison with the years 2013-2014 we observe a decrease in the number of deaths caused by Salmonella.

One of the factors that may have influenced the increase in the number of reported cases was the implementation of the Regulation of the Minister of Health of April 2014 on biological pathogens subject to notification, and standard forms of positive test results for biological pathogens and the circumstances of reporting. padków zachorowań na salmonelozy pochodziła z Polski (2). W krajach Unii Europejskiej w ciągu dwóch lat (2015-2016) salmoneloza była przyczyną 254 zgonów. Obowiązkowej rejestracji w Polsce podlegają zarówno przypadki salmonelozy jelitowej, jak i pozajelitowej.

Celem pracy jest ocena sytuacji epidemiologicznej zachorowań na salmonelozy w latach 2015-2016 w Polsce w porównaniu do lat poprzednich.

\section{MATERIAŁ I METODY}

Sytuacja epidemiologiczna salmoneloz w Polsce w latach 2015 i 2016 została przeanalizowana na podstawie danych zawartych $\mathrm{w}$ rocznych biuletynach "Choroby zakaźne i zatrucia w Polsce" (NIZP-PZH, GIS, Warszawa) (3), (4), z danych z Przeglądu Epidemiologicznego za lata wcześniejsze (5), z danych zawartych w aplikacji Rejestr Ognisk Epidemicznych (ROE) uzyskanych i przekazanych przez stacje sanitarno-epidemiologiczne $\mathrm{w}$ ramach prowadzonych dochodzeń epidemiologicznych w ogniskach, w których czynnikiem etiologicznym były pałeczki Salmonella, a także z informacji z laboratoriów stacji sanitarno-epidemiologicznych dostarczanych do Zakładu Bakteriologii NIZP-PZH.

Zachorowania na salmonelozy jelitowe klasyfikowane są na podstawie definicji przypadku, która została przyjęta przez Komisję Europejską decyzją z dnia 28 kwietnia 2008 r., wprowadzoną do rutynowego nadzoru w Polsce w 2009 r., zmieniającą decyzję numer 2002/253/EC.

\section{WYNIKI}

W Polsce w 2015 r. zarejestrowano ogółem 8650 przypadków salmoneloz, w tym 8418 przypadków salmonelozy jelitowej oraz 232 przypadki salmoneloz pozajelitowych (Tab. I).

W porównaniu do $2014 \mathrm{r}$. jest to łącznie o 221 zachorowań więcej. Zapadalność na 100000 ludności wynosiła 22,5 , co w porównaniu do roku poprzedniego daje wzrost o 0,7 nowo zarejestrowanych zachorowań na 100000 ludności.

W 2016 r. liczba zachorowań na salmonelozy w odniesieniu do roku poprzedniego wzrosła o $16 \%$, odnotowano ogółem 10027 przypadków, 9701 przypadków salmonelozy jelitowej oraz 326 przypadków salmonelozy pozajelitowej. W porównaniu do $2014 \mathrm{r}$. liczba zachorowań na salmonelozy ogółem wzrosła o ponad $19 \%$.

W 2015 r. salmonelozy odzwierzęce były bezpośrednią przyczyną 5 zgonów, natomiast w 2016 r. 8 zgonów. W porównaniu z latami 2013-2014 obserwujemy spadek liczby zgonów spowodowanych pałeczkami Salmonella. 
Table I. Salmonellosis in Poland in 1985-2016. Number of cases, incidence per 100,000 population, percentage of hospitalization and number of deaths

Tabela I. Salmonelozy w Polsce w latach 1985-2016. Liczba zachorowań, zapadalność na 100000 ludności, procent hospitalizowanych oraz liczba zgonów

\begin{tabular}{|c|c|c|c|c|c|c|c|c|c|c|}
\hline \multirow{2}{*}{ Year } & \multicolumn{2}{|c|}{ Intestinal salmonellosis 1) } & \multicolumn{2}{|c|}{ Extraintestinal salmonellosis 2) } & \multicolumn{4}{|c|}{ Total } \\
\cline { 2 - 11 } & $\begin{array}{c}\text { No. of } \\
\text { cases }\end{array}$ & $\begin{array}{c}\text { Incidence } \\
\text { rate }\end{array}$ & $\begin{array}{c}\% \\
\text { hosp. }\end{array}$ & $\begin{array}{c}\text { No. of } \\
\text { cases }\end{array}$ & $\begin{array}{c}\text { Incidence } \\
\text { rate }\end{array}$ & $\begin{array}{c}\% \\
\text { hosp. }\end{array}$ & $\begin{array}{c}\text { No. of } \\
\text { cases }\end{array}$ & $\begin{array}{c}\text { Incidence } \\
\text { rate }\end{array}$ & $\begin{array}{c}\% \\
\text { hosp. }\end{array}$ & $\begin{array}{c}\text { No. of } \\
\text { death }\end{array}$ \\
\hline $1985-19893)$ & 26622 & 70.7 & 37.9 & 22726 & 67.5 & 48.7 & 49242 & 130.7 & 42.9 & 17 \\
\hline $1990-19933)$ & 26455 & 69.2 & 46.9 & 19243 & 50.3 & 48.0 & 45784 & 119.8 & 47.3 & 10 \\
\hline $1994-19983)$ & 26675 & 69.0 & 52.1 & 64 & 0.17 & 93.9 & 26739 & 69.2 & 52.2 & 3 \\
\hline $1999-20033)$ & 20575 & 53.8 & 66.7 & 93 & 0.24 & 90.1 & 20688 & 54.1 & 66.8 & 6 \\
\hline $2004-20093)$ & 13210 & 34.6 & 70.6 & 140 & 0.37 & 91.1 & 13362 & 35.0 & 70.8 & 6 \\
\hline 2009 & 8855 & 23.2 & 69.3 & 117 & 0.31 & 93.2 & 8972 & 23.5 & 69.6 & 6 \\
\hline 2010 & 9549 & 25.0 & 69.7 & 183 & 0.48 & 86.3 & 9732 & 25.5 & 70.0 & 4 \\
\hline 2011 & 8652 & 22.5 & 69.4 & 161 & 0.42 & 93.2 & 8813 & 22.9 & 69.9 & 3 \\
\hline 2012 & 8267 & 21.5 & 69.0 & 177 & 0.46 & 89.3 & 8444 & 21.9 & 69.4 & 7 \\
\hline 2013 & 7407 & 19.2 & 72.0 & 171 & 0.44 & 87.7 & 7578 & 19.7 & 72.4 & 10 \\
\hline 2014 & 8197 & 21.3 & 69.2 & 195 & 0.51 & 93.3 & 8392 & 21.8 & 69.7 & 13 \\
\hline 2015 & 8418 & 21.9 & 71.3 & 232 & 0.60 & 88.8 & 8650 & 22.5 & 71.8 & 5 \\
\hline 2016 & 9701 & 25.2 & 70.5 & 326 & 0.85 & 89.9 & 10027 & 26.1 & 71.1 & 8 \\
\hline
\end{tabular}

1) change in registration: until 1993 only food poisoning, since 1994, food poisoning and other gastrointestinal infections

2) change in registration: up to 1993 other salmonellosis than food poisoning, since 1994, only extraintestinal infections

3) medians

Data sources: Infectious diseases and poisonings in Poland. NIPH-NIH, MoH/CSI. Warsaw. Annual Reports: 1985-2016

Table II. Salmonellosis in Poland in 2015 and 2016. Number of cases and percentage by case definition and voivodeship

Tabela II. Salmonelozy w Polsce w 2015 i 2016 r. Liczba i procentowy udział zachorowań wg kategorii definicji przypadku i województw

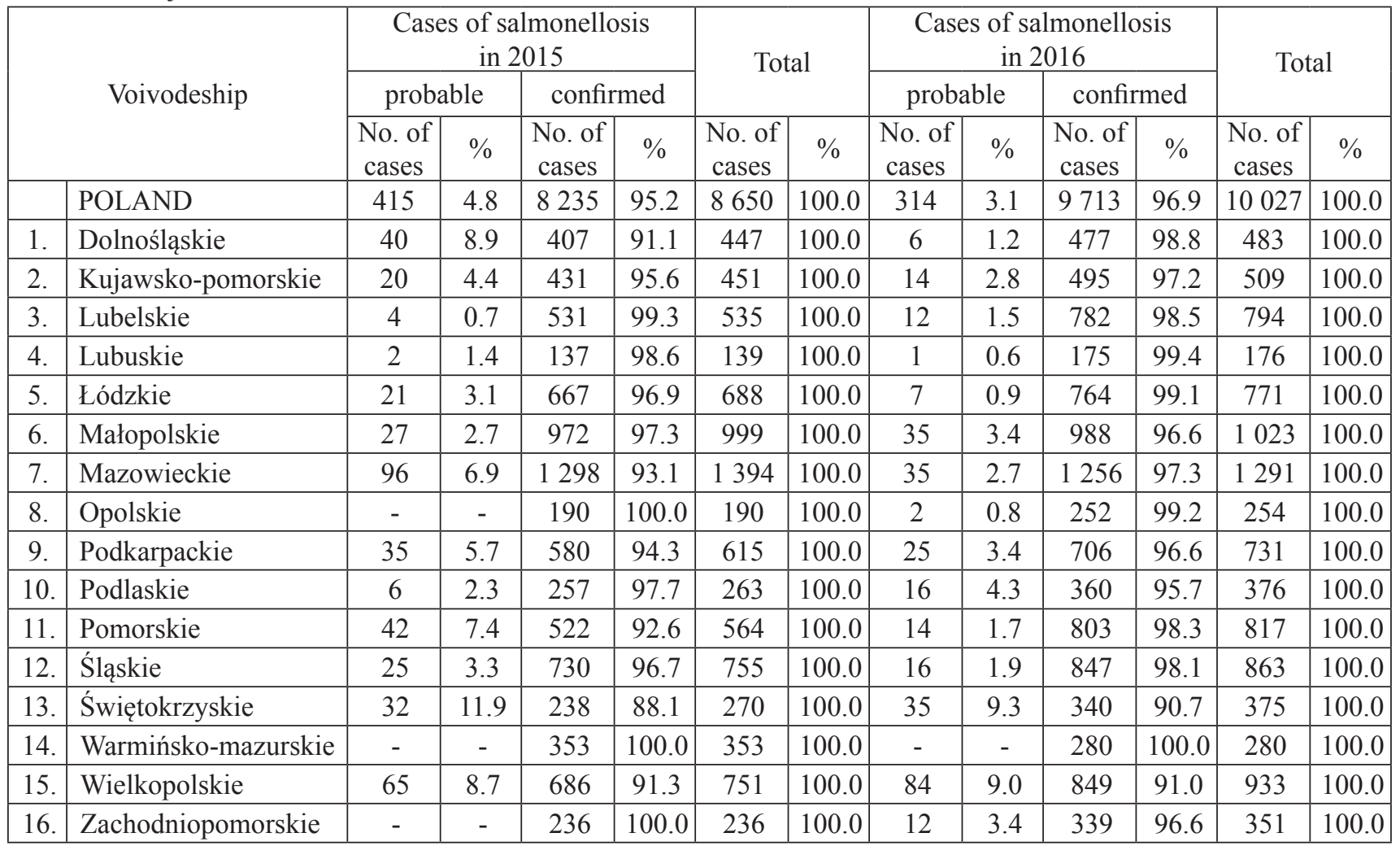

Data sources: Annual reports on cases of infectious diseases and poisonings in Poland (MZ-56)

This legislation was aimed at streamlining and sealing the epidemiological surveillance system in Poland. However, such a large increase, especially in 2016,
Nadal jednym z czynników mogącym mieć wpływ na wzrost liczby zachorowań było wejście w życie rozporządzenia Ministra Zdrowia z kwietnia 2014 r. 
may also be related to the outbreak of infections caused by Salmonella Enteritidis which occurred in in 2016. associated with eggs originating from Poland. Cases in this outbreak were noted, among others in Belgium, Croatia, Denmark, Finland, France, Greece, Hungary, Italy, Luxembourg, the Netherlands, Norway, Slovenia, Sweden and the United Kingdom.

In 2015, the fraction of hospitalization due to salmonellosis amounted to $71.8 \%$, remaining at a similar level as in previous years. In 2016, this percentage decreased slightly and amounted to $71.1 \%$. Fractions of hospitalizations in both years are more than twice as high as the average for the European Union. For Salmonella, both in 2015 and 2016, the EU average ratio was 34.0\%. Persisting high percentage of hospitalization in Poland may indicate a serious underreporting of the cases of salmonellosis.

According to the actual definitions of salmonellosis, number of confirmed cases reported in Poland in 2015 was 8,235 and number of cases classified as probable was 415 (Tab. II).

Confirmed cases, as in previous years, accounted for over 95\% of all reported Salmonella sp. infections. The percentage of probable cases compared to the total number of reported cases of salmonellosis was $4.8 \%$. A year later, the number of confirmed salmonellosis cases increased by $17 \%$ reaching 9713 cases, which is $96.9 \%$ of the total. Number classified as probable was 314 .

As in previous years, in 2015 and 2016, the increase in reported cases of salmonellosis occurred in the summer months (Fig. 1). In the presented years, this increase began in April, and the peak of incidence occurred in July (in 2016, it was over 1500 cases). In 2015, the decrease of reported cases occurred in September, while in 2016 one month later.

Most cases of intestinal salmonellosis in 2015 were reported from 2 voivodeships, Małopolskie 999 cases. Incidence in relation to the previous year increased by $16.5 \%$ and amounted to $29.6 / 100000$, (this was the largest increase among 16 voivodeships) and in Mazowieckie, 1394 cases, however, in this province the incidence in comparison to 2014 decreased and amounted to 26.1/100000 (Tab. III).

An average decrease in the incidence rate by of 0.6 was also observed in 4 other voivodeships - Lubelskie, Łódzkie, Podlaskie and Warmińsko-Mazurskie.

In 2016, incidence of intestinal salmonellosis was similar to the last year, the highest number of cases in the Małopolskie voivodeship - 1,023 cases and in Mazowieckie - 1291 cases. The incidence increased in 14 voivodeships, the largest increase (by 12.2) in comparison to the previous year was recorded in the Lubelskie, it amounted to 37.2 per 100,000 , while the highest decrease in incidence was observed in the Warmińsko-Mazurskie 19.5/100,000. In the previous year it was reported there $24.5 / 100,000$.
„W sprawie biologicznych czynników chorobotwórczych podlegających zgłoszeniu, wzorów formularzy zgłoszeń dodatnich wyników badań w kierunku biologicznych czynników chorobotwórczych oraz okoliczności dokonywania zgłoszeń" mającym na celu usprawnienie oraz uszczelnienie systemu nadzoru epidemiologicznego w Polsce. Jednak tak duży wzrost, szczególnie w roku 2016, należy raczej wiązać z ogniskiem wywołanym w 2016 r. pałeczkami Salmonella Enteritidis, mającym powiązanie z jajami pochodzącymi z Polski. Zachorowania w tym ognisku odnotowano m.in. w Belgii, Chorwacji, Danii, Finlandii, Francji, Grecji, na Węgrzech, we Włoszech, Luksemburgu, Holandii, Norwegii, Słowenii, Szwecji oraz Wielkiej Brytanii.

W 2015 r. odsetek hospitalizacji z powodu salmoneloz wyniósł 71,8 utrzymując się na podobnym poziomie jak w latach poprzednich. W roku 2016 odsetek ten nieznacznie się zmniejszył i wyniósł 71,1\%. Wskaźniki z obydwu lat są przeszło 2 razy wyższe od wskaźników odsetka hospitalizacji w krajach Unii Europejskiej. Dla salmonelozy zarówno w 2015, jak i 2016 r. wskaźnik w UE wynosił $34 \%$. Utrzymujący się na wysokim poziomie odsetek hospitalizacji w Polsce może świadczyć o znacznym niedoszacowaniu w ogólnej liczbie rejestrowanych przypadków salmonelozy.

Zgodnie z obowiązująca definicją w 2015 r. w Polsce zaklasyfikowano i zarejestrowano 8235 przypadków potwierdzonych i 415 przypadków prawdopodobnych salmoneloz (Tab. II).

Przypadki potwierdzone, podobnie jak w poprzednich latach stanowily ponad $95 \%$ wszystkich odnotowanych zachorowań na salmonelozy. Odsetek przypadków prawdopodobnych w porównaniu do ogólnej liczby zarejestrowanych zachorowań na salmonelozy wyniósł 4,8\%. Rok później liczba przypadków potwierdzonych salmoneloz wzrosła o $17 \%$ osiągając poziom 9713 zachorowań, co stanowi 96,9\% wszystkich salmoneloz, natomiast liczba przypadków prawdopodobnych wyniosła 314 .

Podobnie jak w latach poprzednich, tak i w 2015 oraz 2016 r. wzrost rejestrowanych przypadków salmonelozy przypadał na miesiące letnie (Ryc. 1). W prezentowanych latach wzrost ten zaczynał się w kwietniu, a szczyt zachorowań miał miejsce w lipcu (w 2016 r. było to ponad 1500 zachorowań). W 2015 r. spadek zachorowań nastąpił we wrześniu, natomiast w 2016 r. dopiero miesiąc później.

Najwięcej przypadków zachorowań na salmonelozy jelitowe w 2015 r. zostało zarejestrowanych w 2 województwach, małopolskim 999 zachorowań, zapadalność w stosunku do roku poprzedniego wzrosła o $16,5 \%$ i wynosiła 29,6 , (jest to największy wzrost spośród 16 województw) oraz w województwie mazowieckim 1394 zachorowania, jednak w województwie tym zapadalność w porównaniu do 2014 r. spadła i wy- 
In 2015, a total number of reported cases of extraintestinal salmonellosis was 232. It was 37 more cases than in the previous year. The highest number of cases was recorded in three voivodeships: Śląskie 35, Mazowieckie 33 and Pomorskie 25 cases (in Pomorskie it was also the highest incidence rate 1.08/100,000). The lowest number of cases was registered in the Lubuskie, 4 cases, and the lowest incidence was $0.17 / 100,000$ in the Dolnośląskie.

In 2016, the total number of cases of extraintestinal salmonellosis increased significantly and amounted to 326 cases. As in the previous year, the highest number of cases was recorded in the Śląskie Voivodship (42 cases), but the largest, almost twofold increase in incidence, occurred in the Wielkopolskie where it amounted to 40 cases. nosiła 26,1 (Tab. III). Spadek wskaźnika zapadalności o średnio 0,6 widoczny jest również w 4 innych województwach - lubelskim, łódzkim, podlaskim i warmińsko mazurskim.

W 2016 r. sytuacja salmonellozy jelitowej wyglądała podobnie jak w roku ubiegłym, najwięcej przypadków odnotowano w województwie małopolskim 1023 przypadki i w mazowieckim 1291 przypadków. Zapadalność wzrosła w 14 województwach, największy wzrost $(\mathrm{o} 12,2)$ w porównaniu do roku poprzedniego odnotowano w województwie lubelskim, wyniosła ona 37,2 na 100 000, natomiast największy spadek zapadalności obserwowano w województwie warmińsko-mazurskim 19,5 na 100 000, w roku poprzednim 24,5 na 100000 ludności.

Table III. Salmonellosis in Poland in 2010-2016. Number of cases and incidence per 100,000 population by voivodeship Tabela III. Salmonelozy w Polsce w latach 2010-2016. Liczba zachorowań i zapadalność na 100000 ludności wg województw

\begin{tabular}{|c|c|c|c|c|c|c|c|c|c|c|c|c|c|}
\hline \multirow{3}{*}{\multicolumn{2}{|c|}{ Voivodeship }} & \multicolumn{6}{|c|}{ Salmonellosis - total } & \multicolumn{6}{|c|}{ Extraintestinal salmonellosis } \\
\hline & & \multicolumn{2}{|c|}{$\begin{array}{c}2010-2014 \\
\text { (median) }\end{array}$} & \multicolumn{2}{|c|}{2015} & \multicolumn{2}{|c|}{2016} & \multicolumn{2}{|c|}{$\begin{array}{l}\text { 2010-2014 } \\
\text { (median) }\end{array}$} & \multicolumn{2}{|c|}{2015} & \multicolumn{2}{|c|}{2016} \\
\hline & & $\begin{array}{c}\text { No. of } \\
\text { cases }\end{array}$ & $\begin{array}{l}\text { Inci- } \\
\text { dence } \\
\text { rate }\end{array}$ & $\begin{array}{l}\text { No. of } \\
\text { cases }\end{array}$ & $\begin{array}{l}\text { Inci- } \\
\text { dence } \\
\text { rate }\end{array}$ & $\begin{array}{c}\text { No. } \\
\text { of } \\
\text { cases }\end{array}$ & $\begin{array}{l}\text { Inci- } \\
\text { dence } \\
\text { rate }\end{array}$ & $\begin{array}{c}\text { No. of } \\
\text { cases }\end{array}$ & $\begin{array}{c}\text { Inci- } \\
\text { dence } \\
\text { rate }\end{array}$ & $\begin{array}{c}\text { No. of } \\
\text { cases }\end{array}$ & $\begin{array}{l}\text { Inci- } \\
\text { dence } \\
\text { rate }\end{array}$ & $\begin{array}{c}\text { No. of } \\
\text { cases }\end{array}$ & $\begin{array}{c}\text { Inci- } \\
\text { dence } \\
\text { rate }\end{array}$ \\
\hline & POLAND & 8444 & 21.9 & 8650 & 22.5 & 10027 & 26.1 & 177 & 0.46 & 232 & 0.60 & 326 & 0.85 \\
\hline 1. & Dolnośląskie & 317 & 10.9 & 447 & 15.4 & 483 & 16.6 & 5 & 0.17 & 5 & 0.17 & 7 & 0.24 \\
\hline 2. & Kujawsko-pomorskie & 549 & 26.2 & 451 & 21.6 & 509 & 24.4 & 11 & 0.53 & 20 & 0.96 & 31 & 1.49 \\
\hline 3. & Lubelskie & 579 & 26.7 & 535 & 25.0 & 794 & 37.2 & 5 & 0.23 & 5 & 0.23 & 12 & 0.56 \\
\hline 4. & Lubuskie & 135 & 13.2 & 139 & 13.6 & 176 & 17.3 & 4 & 0.39 & 4 & 0.39 & 12 & 1.18 \\
\hline 5. & Łódzkie & 531 & 20.9 & 688 & 27.5 & 771 & 31.0 & 7 & 0.28 & 6 & 0.24 & 10 & 0.40 \\
\hline 6. & Małopolskie & 718 & 21.7 & 999 & 29.6 & 1023 & 30.3 & 11 & 0.33 & 18 & 0.53 & 26 & 0.77 \\
\hline 7. & Mazowieckie & 1794 & 34.3 & 1394 & 26.1 & 1291 & 24.1 & 24 & 0.46 & 33 & 0.62 & 26 & 0.49 \\
\hline 8. & Opolskie & 136 & 13.4 & 190 & 19.0 & 254 & 25.5 & 4 & 0.40 & 5 & 0.50 & 9 & 0.90 \\
\hline 9. & Podkarpackie & 609 & 28.6 & 615 & 28.9 & 731 & 34.4 & 7 & 0.33 & 12 & 0.56 & 28 & 1.32 \\
\hline 10. & Podlaskie & 308 & 25.7 & 263 & 22.1 & 376 & 31.7 & 5 & 0.42 & 7 & 0.59 & 11 & 0.93 \\
\hline 11. & Pomorskie & 578 & 25.2 & 564 & 24.5 & 817 & 35.3 & 17 & 0.74 & 25 & 1.08 & 33 & 1.43 \\
\hline 12. & Śląskie & 633 & 13.7 & 755 & 16.5 & 863 & 18.9 & 27 & 0.58 & 35 & 0.76 & 42 & 0.92 \\
\hline 13. & Świętokrzyskie & 238 & 18.8 & 270 & 21.4 & 375 & 29.9 & 5 & 0.39 & 9 & 0.71 & 9 & 0.72 \\
\hline 14. & Warmińsko-mazurskie & 516 & 35.6 & 353 & 24.5 & 280 & 19.5 & 7 & 0.48 & 9 & 0.62 & 15 & 1.04 \\
\hline 15. & Wielkopolskie & 684 & 19.8 & 751 & 21.6 & 933 & 26.8 & 18 & 0.53 & 21 & 0.60 & 40 & 1.15 \\
\hline 16. & Zachodniopomorskie & 291 & 16.9 & 236 & 13.8 & 351 & 20.5 & 12 & 0.70 & 18 & 1.05 & 15 & 0.88 \\
\hline
\end{tabular}

Data sources: Infectious diseases and poisonings in Poland. NIPH-NIH, CSI. Warsaw. Annual Reports: 2010-2016

As in previous years, the highest incidence of intestinal salmonellosis in 2015 and 2016 was recorded in the age group 0-4, in 2015 it was 3,549 cases, in $2016-3,938$, the most cases occurred in children 2 and 3 years old (Tab. IV). Among this group of children also incidence was the highest. In 2015 it was 248.4 $/ 100,000$, while in 2016 it increased to 253.1 .

Among the cases of parental salmonellosis in 2015 and 2016, the majority of was reported in the age group $60+$. The overall incidence of extraintestinal salmonellosis in 2016, as compared to the previous year increased by $40.5 \%$.
W 2015 r. zarejestrowano łącznie 232 przypadki salmoneloz pozajelitowych, jest to o 37 przypadków więcej w porównaniu do roku poprzedniego. Największa liczba zachorowań została odnotowana w trzech województwach - śląskim 35, mazowieckim 33 i pomorskim 25 zachorowań (w pomorskim również największa zapadalność 1,08 na 100000 ludności). Najmniej zachorowań zarejestrowano w województwie lubuskim 4 przypadki, a najmniejszą zapadalność 0,17 na 100000 ludności w województwie dolnośląskim. 
Data provided by sanitary-epidemiological stations through the ROE system show that in 2015, number of reported foodborne outbreaks caused by Salmonella was 190. In 154 of them the etiological factor was Salmonella Enteritidis. The number of outbreaks in 2015, in which the number of cases exceeded 30 was 11 (Tab. V). In all of these outbreaks, the etiological factor was Salmonella Enteritidis. The outbreak with the highest number of cases was recorded in September in the Mazowieckie voivodeship. This outbreak occurred in the kindergarten, 91 got sick including 84 children. 9 of them were hospitalized. Another two large outbreaks were detected in the Wielkopolskie and Podkarpackie voivodeships, both occurred in the nursery, the number of patients in these outbreaks was 59 in the first one and 47 in the second. All patients were children. Other places where numbers of cases exceeded 30 were in 2015 banquet rooms.

In 2016, 240 outbreaks of foodborne infections due to Salmonella were reported in the ROE system, out of which 205 were caused by $S$. Enteritidis.
W 2016 r. łączna liczba zachorowań na salmonelozy pozajelitowe znacznie wzrosła i wyniosła 326 przypadków. Tak jak w poprzednim roku najwięcej zachorowań odnotowano w województwie śląskim 42 przypadki, natomiast największy, prawie dwukrotny wzrost zachorowań pojawił się w województwie wielkopolskim, i wyniósł 40 przypadków.

Podobnie jak w ubiegłych latach najwięcej zachorowań na salmonelozy jelitowe w 2015 i 2016 r. zarejestrowano w grupie wiekowej 0-4 lata, w 2015 r. było to 3549 zachorowań, w 2016 r. 3 938, najwięcej przypadków wystąpiło u dzieci w wieku między 2 a 3 r.ż. (Tab. IV). Wśród tej grupy dzieci największa była również zapadalność, w 2015 r. wynosiła 248,4 na 100 000 ludności, natomiast w 2016 r. wzrosła do 253,1.

Wśród salmoneloz pozajelitowych na przestrzeni 2015 i 2016 r. najwięcej przypadków zarejestrowano w grupie wiekowej 60+. Ogólna liczba zachorowań na salmonelozy pozajelitowe między 2015 a 2016 rokiem zwiększyła się o $40,5 \%$.

Table IV. Salmonellosis in Poland in 2010-2016. Number of cases. incidence per 100.000 population. and percentage of cases by age

Tabela IV. Salmonelozy w Polsce w latach 2010-2016. Liczba zachorowań. zapadalność na 100000 ludności i udział procentowy wg wieku

\begin{tabular}{|c|c|c|c|c|c|c|c|c|c|c|c|c|c|c|c|c|}
\hline \multirow{3}{*}{$\begin{array}{l}\text { Age } \\
\text { group }\end{array}$} & \multicolumn{8}{|c|}{ Salmonellosis - total } & \multicolumn{8}{|c|}{ Extraintestinal salmonellosis } \\
\hline & \multicolumn{2}{|c|}{$\begin{array}{c}\text { 2010-2014 } \\
\text { (median) }\end{array}$} & \multicolumn{3}{|c|}{2015} & \multicolumn{3}{|c|}{2016} & \multicolumn{2}{|c|}{$\begin{array}{c}2010-2014 \\
\text { (median) }\end{array}$} & \multicolumn{3}{|c|}{2015} & \multicolumn{3}{|c|}{2016} \\
\hline & $\begin{array}{c}\text { No. } \\
\text { of } \\
\text { cases }\end{array}$ & $\begin{array}{l}\text { Inci- } \\
\text { dence } \\
\text { rate }\end{array}$ & $\begin{array}{c}\text { No. } \\
\text { of } \\
\text { cases }\end{array}$ & $\begin{array}{l}\text { Inci- } \\
\text { dence } \\
\text { rate }\end{array}$ & $\%$ & $\begin{array}{c}\text { No. of } \\
\text { cases }\end{array}$ & \begin{tabular}{|l} 
Inci- \\
dence \\
rate
\end{tabular} & $\%$ & $\begin{array}{c}\text { No. } \\
\text { of } \\
\text { cases }\end{array}$ & \begin{tabular}{|c|} 
Inci- \\
dence \\
rate
\end{tabular} & $\begin{array}{c}\text { No. } \\
\text { of } \\
\text { cases }\end{array}$ & $\begin{array}{l}\text { Inci- } \\
\text { dence } \\
\text { rate }\end{array}$ & $\%$ & $\begin{array}{c}\text { No. } \\
\text { of } \\
\text { cases }\end{array}$ & $\begin{array}{l}\text { Inci- } \\
\text { dence } \\
\text { rate }\end{array}$ & $\%$ \\
\hline Total & 8444 & 21.9 & 8650 & 22.5 & 100.0 & 10027 & 26.1 & 100.0 & 177 & 0.46 & 232 & 0.60 & 100.0 & 326 & 0.85 & 100.0 \\
\hline 0 & 657 & 171.0 & 524 & 144.7 & 6.1 & 605 & 165.8 & 6.0 & 11 & 2.86 & 7 & 1.93 & 3.0 & 8 & 2.19 & 2.5 \\
\hline 1 & 956 & 236.0 & 923 & 248.4 & 10.7 & 943 & 253.1 & 9.4 & 5 & 1.32 & 12 & 3.23 & 5.2 & 6 & 1.61 & 1.8 \\
\hline 2 & 781 & 190.4 & 857 & 226.0 & 9.9 & 830 & 223.0 & 8.3 & 5 & 1.18 & 12 & 3.17 & 5.2 & 3 & 0.81 & 0.9 \\
\hline 3 & 655 & 169.3 & 656 & 167.0 & 7.6 & 829 & 218.5 & 8.3 & 1 & 0.26 & 1 & 0.25 & 0.4 & 2 & 0.53 & 0.6 \\
\hline 4 & 540 & 141.8 & 589 & 145.2 & 6.8 & 731 & 186.1 & 7.3 & 2 & 0.48 & 1 & 0.25 & 0.4 & 0 & 0.00 & 0.0 \\
\hline $0-4$ & 3739 & 181.1 & 3549 & 185.7 & 41.0 & 3938 & 209.2 & 39.3 & 25 & 1.21 & 33 & 1.73 & 14.2 & 19 & 1.01 & 5.8 \\
\hline $5-9$ & 1229 & 66.5 & 1517 & 74.2 & 17.5 & 2100 & 101.3 & 20.9 & 4 & 0.22 & 5 & 0.24 & 2.2 & 11 & 0.53 & 3.4 \\
\hline $10-19$ & 711 & 16.4 & 740 & 19.4 & 8.6 & 990 & 26.4 & 9.9 & 5 & 0.12 & 5 & 0.13 & 2.2 & 5 & 0.13 & 1.5 \\
\hline $20-29$ & 515 & 8.7 & 469 & 8.8 & 5.4 & 426 & 8.3 & 4.2 & 5 & 0.09 & 4 & 0.07 & 1.7 & 10 & 0.19 & 3.1 \\
\hline $30-39$ & 438 & 7.1 & 416 & 6.6 & 4.8 & 453 & 7.1 & 4.5 & 9 & 0.15 & 8 & 0.13 & 3.4 & 12 & 0.19 & 3.7 \\
\hline $40-49$ & 323 & 6.6 & 351 & 7.0 & 4.1 & 376 & 7.3 & 3.7 & 12 & 0.25 & 10 & 0.20 & 4.3 & 21 & 0.41 & 6.4 \\
\hline $50-59$ & 489 & 8.6 & 450 & 8.4 & 5.2 & 452 & 8.7 & 4.5 & 29 & 0.50 & 30 & 0.56 & 12.9 & 49 & 0.95 & 15.0 \\
\hline $60+$ & 1091 & 13.0 & 1158 & 13.4 & 13.4 & 1292 & 14.5 & 12.9 & 91 & 1.16 & 137 & 1.58 & 59.1 & 199 & 2.23 & 61.0 \\
\hline
\end{tabular}

Data sources: Infectious diseases and poisonings in Poland. NIPH-NIH. CSI. Warsaw. Annual Reports: 2010-2016

In 12 outbreaks, the number of patients exceeded 30 people. The largest outbreak occurred in school in the Pomorskie Voivodship. In this outbreak 260 people were affected, of whom over $90 \%$ were below 14 years of age. Two of those cases were hospitalized. One outbreak in the kindergarten was also very large. Number of reported cases was 103, including 101 children. As in 2015 most of outbreaks of foodborne infections caused by Salmonella occurred in the kindergartens. The most frequently isolated serotype was $S$. Enteritidis. Out of the 12 outbreaks reported in 2016, $S$. Typhimurium was isolated only in one.
Z danych przekazanych przez stacje sanitarno-epidemiologiczne poprzez system ROE wynika, że w 2015 r. zgłoszono 190 ognisk pokarmowych wywołanych pałeczkami Salmonella, w tym 154, gdzie czynnikiem etiologicznym były pałeczki Salmonella Enteritidis. Łączna liczba ognisk w 2015 r., w których liczba chorych w ognisku przekroczyła 30 osób to 11 (Tab. V). We wszystkich tych ogniskach czynnikiem etiologicznym była Salmonella Enteritidis. Ognisko z największą liczbą chorych odnotowano we wrześniu, $\mathrm{w}$ województwie mazowieckim. 
Table V. Salmonellosis in Poland in 2015 and 2016. Outbreaks of foodborne infections caused by Salmonella involving 30 cases and more.

Tabela V. Salmonelozy w Polsce w 2015 i 2016 r. Charakterystyka największych ognisk zbiorowych zatruć pokarmowych wywołanych przez pałeczki Salmonella (30 i więcej zachorowań w ognisku)

\begin{tabular}{|c|c|c|c|c|c|c|}
\hline Number & $\begin{array}{c}\text { Number } \\
\text { of hospitali- }\end{array}$ & \multirow{2}{*}{$\begin{array}{l}\text { Etiological } \\
\text { agent } \\
\text { (Salmonella } \\
\text { serotype) }\end{array}$} & \multirow{2}{*}{ Setting of outbreak occurance } & \multicolumn{2}{|c|}{ Place of outbreak occurance } & \multirow{2}{*}{ Month } \\
\hline \multicolumn{2}{|c|}{$\begin{array}{l}\text { (of which } \\
\text { children age } 0-14 \text { ) }\end{array}$} & & & voivodeship & district & \\
\hline \multicolumn{7}{|c|}{2015} \\
\hline $91(84)$ & $9(9)$ & Enteritidis & Kindergarten - 5 settings (catering) & mazowieckie & Warszawa & September \\
\hline $59(59)$ & $2(2)$ & Enteritidis & Nursery & wielkopolskie & Poznań & January \\
\hline $47(47)$ & $1(1)$ & Enteritidis & Nursery & podkarpackie & $\begin{array}{c}\text { ropczycko } \\
\text {-sędziszowski }\end{array}$ & March \\
\hline $42(4)$ & $7(4)$ & Enteritidis & Weeding House & małopolskie & dąbrowski & June \\
\hline $42(5)$ & $16(3)$ & Enteritidis & Banquet room & dolnośląskie & polkowicki & August \\
\hline $40(40)$ & $2(2)$ & Enteritidis & Kindergarten & lubelskie & puławski & May \\
\hline $39(6)$ & $15(6)$ & Enteritidis & Fire-station (banquet room) & kujawsko-pomorskie & rypiński & August \\
\hline $38(2)$ & $11(2)$ & Enteritidis & Fire-station (banquet room) & mazowieckie & garwoliński & October \\
\hline $37(1)$ & $6(1)$ & Enteritidis & Fire-station (banquet room) & świętokrzyskie & kielecki & August \\
\hline $33(33)$ & $8(8)$ & Enteritidis & Kindergarten & lubelskie & puławski & April \\
\hline $32(3)$ & $7(3)$ & Enteritidis & Hotel restaurant & śląskie & lubliniecki & June \\
\hline \multicolumn{7}{|c|}{2016} \\
\hline $260(240)$ & $2(2)$ & Enteritidis & School - 2 settings & pomorskie & pucki, wejherowski & November \\
\hline $103(101)$ & $3(3)$ & Enteritidis & Kindergarten & dolnośląskie & Legnica, legnicki & October \\
\hline $82(80)$ & $11(11)$ & Enteritidis & Kindergarten & wielkopolskie & pilski, złotowski, & September \\
\hline $57(41)$ & $3(3)$ & Enteritidis & School (banquet) & wielkopolskie & ostrowski & October \\
\hline $52(50)$ & $3(3)$ & Enteritidis & School & małopolskie & Kraków, krakowski & November \\
\hline $46(41)$ & $5(5)$ & Enteritidis & School & podlaskie & Białystok, białostocki & May \\
\hline $44(44)$ & $11(11)$ & Enteritidis & Kindergarten - 3 settings (catering) & zachodniopomorskie & stargardzki & April \\
\hline $43(8)$ & $8(3)$ & Enteritidis & Hotel & małopolskie & $\begin{array}{c}\text { Bielsko-Biała, Bytom, } \\
\text { Ruda Śląska, Sos- } \\
\text { nowiec, bielski, str- } \\
\text { zelecki, tarnogórski }\end{array}$ & September \\
\hline $34(2)$ & $5(1)$ & Typhimurium & Fire-station (banquet room) & lubelskie & $\begin{array}{l}\text { Biała Podlaska, bialski, } \\
\text { radzyński, parczewski }\end{array}$ & September \\
\hline $34(34)$ & $2(2)$ & Enteritidis & Kindergarten & lubelskie & lubartowski, świdnicki & March \\
\hline $31(0)$ & $0(0)$ & Enteritidis & Restaurant & mazowieckie & Warszawa & August \\
\hline $30(30)$ & $2(2)$ & Enteritidis & Kindergarten & pomorskie & chojnicki & October \\
\hline
\end{tabular}

Data sources: Forms from the outbreaks study of food poisonings and intestinal infections sent to the Department of Epidemiology of NIPH-NIH by sanitary-epidemiological stations

Both in 2015 and 2016, the isolated Salmonella serotypes were Enteritidis, Typhimurium and Infantis. Salmonella Enteritidis in 2015 was reported in almost $77 \%$ of all salmonellosis cases, $16 \%$ of them were isolated from patients in the Mazowieckie voivodeship (Tab. VI). The smallest number - 115 cases of salmonellosis of this serotype was reported in the Lubuskie Voivodship. In the whole country $S$. Typhimurium in 2015 was the cause of 285 cases and $S$. Infantis of 100 cases.

In 2016, the number of isolated $S$. Enteritidis increased significantly, causing almost $14 \%$ more cases than in 2015. As in the previous year, the largest number of Salmonella specimens of this serotype was reported in the Mazowieckie. In this year number of $S$. Typhimurium was 356, and S.Infantis 116 .

In comparison to previous years, there is evident increase in the number of cases in which serotype has not been specified, particularly among children of the age $0-4$ (Tab. VII).
Ognisko to miało miejsce w przedszkolu, zachorowało w nim 91 osób, w tym 84 dzieci, 9 z nich było hospitalizowanych. Kolejne dwa duże ogniska wykryto w województwie wielkopolskim oraz podkarpackim, oba wystąpiły w żłobku, liczba chorych w tych ogniskach wyniosła $59 \mathrm{w}$ pierwszym i $47 \mathrm{w}$ drugim ognisku (w tym wszyscy chorzy to dzieci). Oprócz przedszkoli, miejscami, w których najczęściej dochodziło w 2015 r. do zbiorowych zachorowań z liczbą chorych powyżej 30 osób, były sale bankietowe.

W 2016 r. w systemie ROE zgłoszono 240 ognisk zakażeń pokarmowych spowodowanych pałeczkami Salmonella, w tym 205 wywołanych przez $S$. Enteritidis. W 12 ogniskach liczba chorych przekroczyła 30 osób. Największym ogniskiem było ognisko szkolne w województwie pomorskim, w którym zachorowało 260 osób, w tym ponad $90 \%$ chorych było w wieku do 14 r.ż., dwie z nich były hospitalizowane. Bardzo dużym ogniskiem było również ognisko przedszkolne. 


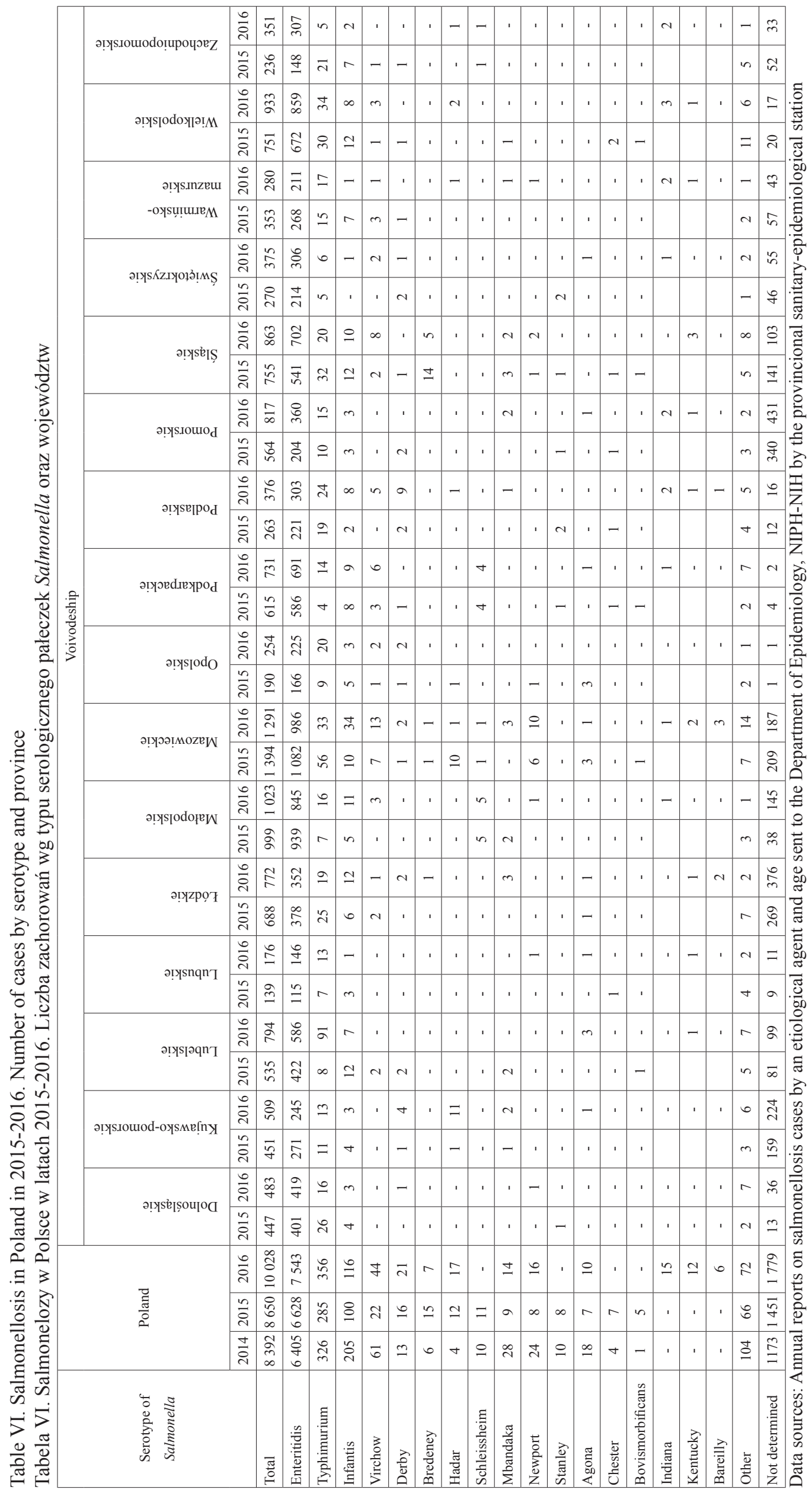




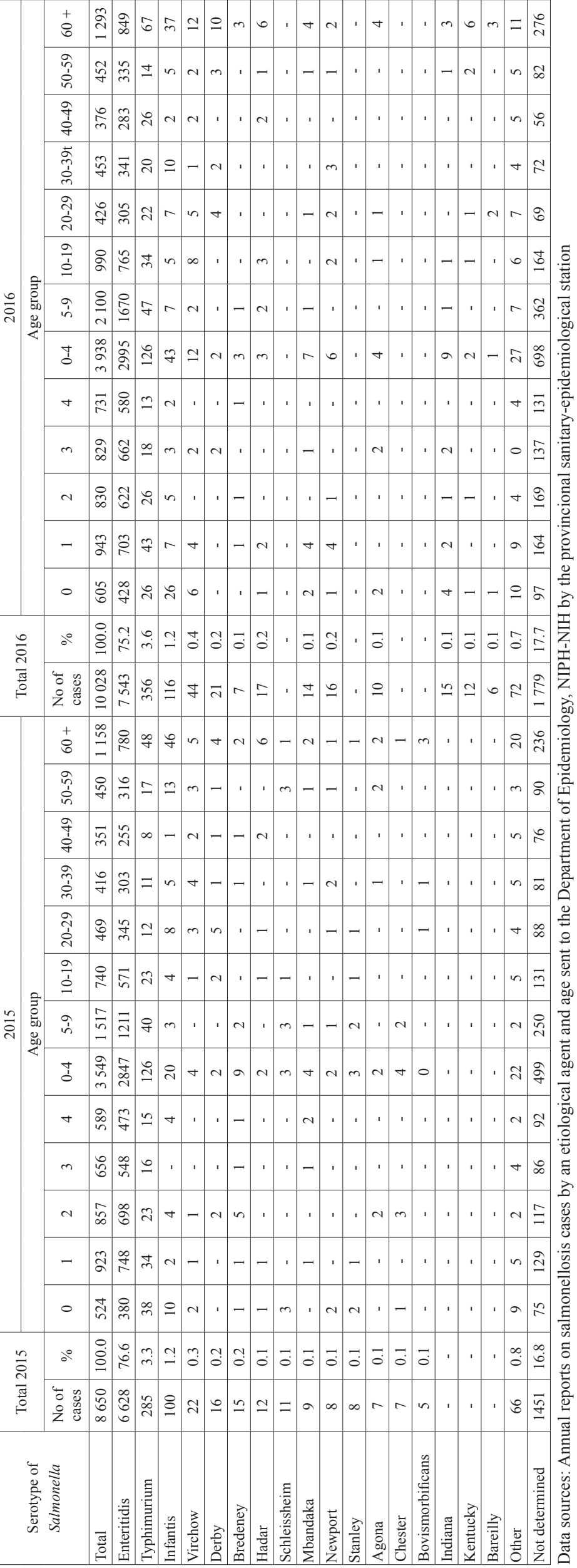


In 2015 , the serotype was not specified in 1,451 patients, in 2016 in 1,779 (an increase of 22\%). In the Pomorskie in 2014 number of cases in which Salmonella was not serotyped was 241 , while in 2016 this number was 431 , causing a $80 \%$ increase. The largest, triple increase in the number of cases in which the serotype was not specified was in Małopolskie voivodeship (38 isolates not serotyped in 2015 and 145 in 2016). The smallest numbers of not serotyped Salmonella were reported from the following provinces: Lubuskie (20), Opolskie (2) and Podkarpackie (6).

In 2015, number of bacteriological tests for Salmonella among people working with food was higher than in the previous year. Percentage of people with positive results in this sector amounted to $0.2 \%$ as in the previous two years (Tab. VIII).

Among the contacts of cases with Salmonella infection, $8.4 \%$ were positive. Also $40.6 \%$ of healthy people after infection were tested positive for Salmonella.
Zarejestrowano w nim 103 chore osoby, w tym 101 z nich to dzieci. Najczęściej ogniska zakażeń pokarmowych wywołane pałeczkami Salmonella miały miejsce podobnie jak w roku 2015 w przedszkolach. Izolowano w nich od chorych głównie pałeczki $S$. Enteritidis. W jednym z 12 wspomnianych ognisk w 2016 r. wyizolowano $S$. Typhimurium.

Zarówno w 2015 jak i 2016 r. do najczęściej izolowanych serotypów Salmonella należały Enteritidis, Typhimurium i Infantis. Salmonella Entritidis w 2015 r. odpowiadała za prawie $77 \%$ wszystkich salmoneloz, z czego $16 \%$ zostało wyizolowanych od chorych w województwie mazowieckim (Tab. VI). Najmniej - 115 zachorowań na salmonelozy o tym typie serologicznym miało miejsce $\mathrm{w}$ województwie lubuskim. S. Typhimurium w 2015 r. odpowiadała za spowodowanie 285 zachorowań, natomiast Salmonella Infantis za 100 przypadków w skali całego kraju.

Table VIII. Salmonellosis in Poland in 2015 and 2016. Results of bacteriological examinations of different groups of persons: cases, convalescents, carriers, contacts, food staff and others

Tabela VIII. Salmonelozy w Polsce w 2015 i 2016 r. Wyniki badań bakteriologicznych w kierunku pałeczek Salmonella i Shigella prowadzonych w laboratoriach stacji sanitarno-epidemiologicznych wg grup badanych osób

\begin{tabular}{|c|c|c|c|c|c|c|c|}
\hline \multirow{2}{*}{ Tested groups } & \multirow{2}{*}{$\begin{array}{l}\text { Number of } \\
\text { tested people }\end{array}$} & \multicolumn{6}{|c|}{ Number of people positive for Sallmonella } \\
\hline & & Total & $(\%)$ & $S$. Typhi & S. Paratyphi & other Salm. & Shigella \\
\hline \multicolumn{8}{|c|}{2015} \\
\hline Cases & 16653 & 1341 & 8,1 & - & 1 & 1340 & 6 \\
\hline Convalescents & 6948 & 2822 & 40,6 & - & 5 & 2817 & - \\
\hline Carriers & 5301 & 1347 & 25,4 & 2 & 3 & 1342 & - \\
\hline Contacts & 12298 & 1030 & 8,4 & - & 1 & 1029 & - \\
\hline Professionals & 433571 & 898 & 0,2 & 1 & 2 & 895 & 2 \\
\hline Other & 8312 & 36 & 0,4 & - & - & 36 & - \\
\hline \multicolumn{8}{|c|}{2016} \\
\hline Cases & 15092 & 1404 & 9,3 & - & 1 & 1403 & 2 \\
\hline Convalescents & 8221 & 3462 & 42,1 & - & - & 3462 & 2 \\
\hline Carriers & 5548 & 1518 & 27,4 & 3 & - & 1515 & - \\
\hline Contacts & 15506 & 1356 & 8,7 & - & - & 1356 & 1 \\
\hline Professionals & 443419 & 1015 & 0,2 & - & 3 & 1012 & 1 \\
\hline Other & 8080 & 16 & 0,2 & - & - & 16 & - \\
\hline
\end{tabular}

Data sources: Annual reports on results of laboratory tests for Salmonella and Shigella sent to the Department of Bacteriology, NIPH-NIH by the provincional sanitary-epidemiological station

In 2016, among people working with food, the percentage of positive Salmonella tests remained at the same level as in previous years and amounted to $0.2 \%$ among the surveyed 433571 people.

\section{SUMMARY AND CONCLUSIONS}

1. In 2015 in Poland 8,650 cases of salmonellosis were reported to the routine surveillance system. The incidence was $22.5 / 100,000$ population, while
W 2016 r. liczba wyizolowanych pałeczek Salmonella Enteritidis znacznie wzrosła, powodując prawie 14\% więcej zachorowań niż w roku 2015. Podobnie jak w roku ubiegłym najwięcej pałeczek Salmonella z tym typem serologicznym, odnotowano w województwie mazowieckim. W tym roku zarejestrowano również więcej zachorowań wywołanych pałeczkami $S$. Typhimurium, łącznie 356 przypadków oraz $S$. Infantis 116 przypadków. 
in 2016 there was a significant increase compared to 2014 and 2015. There were reported 10027 Salmonella cases. Such an increase in incidence of foodborne infections caused by Salmonella sp. May be related to the outbreak of a foodborne infections in 2016, which occurred in more than a dozen EU countries and was caused by the consumption of eggs from Polish farms. To a lesser extent, this increase may be related to the regulation introduced in 2014, for the purpose of sealing the surveillance of infectious diseases by introducing the obligatory reporting by laboratories of positive test results to the surveillance system.

2. The percentage of hospitalization in 2015 and 2016 was maintained, as in previous years, at a very high level (over 70\%), probably related to scarcity of laboratory tests commissioned by GPs to patients with gastro-intestinal obstructions. Ń Such a high percentage of hospitalizations indicates a significant under-reporting of no hospitalized cases of salmonellosis in Poland.

3 . In the whole country, the highest incidence of intestinal salmonellosis in 2015 and 2016, as in previous years, was recorded among children aged $0-4$. Children 2 and 3 years old were particularly affected. They constituted up to $47 \%$ of cases in the above-mentioned age range. In contrast, extraintestinal salmonellosis is most common among people aged $60+$.

\section{REFERENCES}

1. EFSA (European Food Safety Authority) and ECDC (European Centre for Disease Prevention and Control), 2016. The European Union summary report on trends and sources of zoonoses, zoonotic agents and food-borne outbreaks in 2015. EFSA Journal 2016;14(12):4634,231 pp. doi:10.2903/j. efsa.2016.4634

2. EFSA (European Food Safety Authority) and ECDC (European Centre for Disease Prevention and Control), 2017. The European Union summary report on trends and sources of zoonoses, zoonotic agents and food-borne outbreaks in 2016. EFSA Journal 2017;15(12):5077, 228 pp. https://doi. org/10.2903/j.efsa.2017.5077

3. Infectious Diseases and Poisonings in Poland in 2015; Bulletins of the National Institute of Public Health and Chief Sanitary Inspectorate: Warszawa, Poland, 2016

4. Infectious Diseases and Poisonings in Poland in 2016; Bulletins of the National Institute of Public Health and Chief Sanitary Inspectorate: Warszawa, Poland, 2017
W porównaniu do lat ubiegłych widoczny jest wzrost liczby przypadków, w których nie określono serotypu, szczególnie widoczny wśród dzieci w wieku od 0 do 4 lat (Tab. VII). W 2015 r. serotyp nie został określony u 1451 chorych, w 2016 r. u 1779 (wzrost o $22 \%$ ). W województwie pomorskim w 2014 r. zarejestrowano 241 przypadków, w których nie określono serotypu pałeczek Salmonella, natomiast w 2016 r. 431, co stanowi blisko $80 \%$ wzrost. Największy, bo aż 3-krotny wzrost liczby zachorowań, w których nie określono serotypu miał miejsce $\mathrm{w}$ województwie małopolskim (38 izolatów z nieokreślonym typem serologicznym w 2015 i 145 w 2016 r.). Najmniej nieokreślonych pałeczek Salmonella zgłoszono z terenu województw: lubuskiego (20), opolskiego (2) i podkarpackiego (6).

W 2015 r. wykonano więcej niż w roku ubiegłym badań bakteriologicznych w kierunku pałeczek Salmonella u osób pracujących z żywnością, a odsetek osób $\mathrm{z}$ dodatnim wynikiem badań $\mathrm{w}$ tej branży wyniósł tak jak w poprzednich dwóch latach 0,2\% (Tab. VIII). Wśród przebadanych osób z kontaktu z chorym 8,4 \% $\mathrm{z}$ nich miało dodatni wynik w kierunku pałeczek $\mathrm{Sal}$ monella, natomiast wśród ozdrowieńców $40,6 \%$ przebadanych osób.

W 2016 r. wśród osób pracujących z żywnością odsetek z dodatnim wynikiem badań w kierunku pałeczek Salmonella utrzymał się na tym samym poziomie jak w latach ubiegłych i wyniósł $0,2 \%$ na przebadanych 433571 osób.

\section{PODSUMOWANIE I WNIOSKI}

1. W 2015 r. zarejestrowano 8650 zachorowań na salmonelozy odzwierzęce ogółem, zapadalność wyniosła 22,5 na 100000 ludności, natomiast w 2016 r. nastąpił znaczny wzrost w porównaniu do 2014 oraz do 2015 r., zarejestrowano 10027 przypadków salmonelozy. Taki wzrost zarejestrowanych zachorowań jest prawdopodobnie w dużej mierze konsekwencją wykrytego w 2016 r. ogniska zakażenia pokarmowego, które objęło kilkanaście krajów UE, a którego czynnikiem etiologicznym okazały się być jaja pochodzące z Polski. Wzrost ten wynika również, choć w znacznie mniejszym stopniu z wprowadzonego w 2014 r. rozporządzenia, którego celem było uszczelnienie nadzoru nad chorobami zakaźnymi poprzez wprowadzenie obligatoryjności zgłaszania przez laboratoria dodatnich wyników badań do stacji sanitarno-epidemiologicznych.

2. Odsetek hospitalizacji w 2015 i 2016 r. utrzymywał się, podobnie jak w latach ubiegłych, na bardzo wysokim poziomie (ponad 70\%), co świadczy o zlecaniu wciąż zbyt małej liczby badań labo- 
Received: 5.12.2018

Accepted for publication: 10.12.2018

Otrzymano: 5.12.2018 r.

Zakwalifikowano do druku: 10.12.2018 r.

\section{Address for correspondence:}

Adres do korespondencji:

Dr Małgorzata Sadkowska-Todys

Zakład Epidemiologii

Narodowy Instytut Zdrowia Publicznego - Państwowy

Zakład Higieny

ul. Chocimska 24, 00-791 Warszawa

tel. 022 54-21-215 ratoryjnych przez lekarzy pierwszego kontaktu u chorych z nieżytami żołądkowo-jelitowymi. Tak wysoki odsetek hospitalizacji wskazuje na znaczne niedorejestrowanie przypadków zachorowań na salmonelozy w Polsce.

3. W skali całego kraju najwięcej zachorowań na salmonelozy jelitowe w 2015 i 2016 r., podobnie jak w latach ubiegłych, odnotowano wśród dzieci w przedziale wiekowym 0-4, szczególnie narażone były dzieci w wieku od 2 do 3 r.ż i stanowiły aż $47 \%$ przypadków w wyżej wymienionym przedziale wiekowym. Natomiast slamonelozy pozajelitowe najczęściej występują wśród osób w wieku 60+. 